\title{
Is the so-called 'Rusk Letter' be a Critical Evidence of Japan's Territorial Claim to Dokdo Island?
}

\author{
Yuji Hosaka*
}

This paper provides detailed analysis of the so-called 'Rusk Letter' which has been generally referred to as an evidence of Japan's territorial claim to Dokdo island. The Rusk Letter is a diplomatic epistle which was drafted by Dean Rusk, the US Assistant Secretary of State and sent to the Korean Embassy in the US on August 10, 1951. This letter considers Dokdo as Japan's territory. However, the Rusk Letter has been legally and historically criticized from mainly two aspects. First, the Rusk Letter referred to the ownership of Dokdo only considering the Japanese position which was not true. Second, this letter was a confidential and unofficial document which was sent only to Korea; Japan and even the US Embassy to Korea did not know the Rusk Letter. It did not influence on the decision of Peace Treaty. Therefore, the Rusk Letter cannot be a critical evidence of Japan's territorial claim over Dokdo.

\section{Keywords}

Rusk Letter, Dokdo, Takeshima, Territorial Claim, Evidence, San Francisco Peace Treaty, Cairo Declaration, Potsdam Declaration, US draft, USBritish Draft

* Professor of Political Science at Sejong University, Seoul, Korea. B.A.(Tokyo), Ph.D.(Korea). ORCID: https://orcid. org/0000-0001-6655-0329. This research was supported by Sejong University Research Fund. The author may be contacted at: hosaka@sejong.ac.kr / Address: 313 Saenal-gwan Sejong University Gunja-dong, Gwangjin-gu, Seoul 143-747 Korea. 


\section{Introduction}

Today, there are three major maritime territorial issues in Northeast Asia: (1) Kurill Islands; (2) Senkaku Islands (Dioyudao); and (3) Dokdo Island (Takeshima), to which Japan is a party. This article will cast light upon the Dokdo problem. In particular, the author will provide a detailed analysis of the so-called 'Rusk Letter' which has generally been referred to as an evidence of Japan's territorial claim to Dokdo Island.

The Rusk Letter is a diplomatic epistle which was drafted by Dean Rusk, the United States Assistant Secretary of State and sent to the Korean Embassy in the United States on August 10, 1951. Japan argues that this letter is crucial evidence that Dokdo belongs to Japan, because it states Dokdo is part of Japanese territory. Further, Japan widely publicized its territorial claim over Dokdo by both uploading this letter to "The Issue of Takeshima" website ${ }^{1}$ of the Ministry of Foreign Affairs, and inserting it into media steams such as the pamphlet "10 Issue of Takeshima," the leaflet "Japan's Position on Takeshima" and the video "Takeshima-Seeking a Solution based on Law and Dialogue. ${ }^{3}$ However, these arguments have been legally and historically criticized from two pertinent aspects.

The primary purpose of this research is to examine whether the Rusk Letter is a decisive evidence of Japan's territorial claim over Dokdo. The author will refute Japan's claim by enumerating objective facts and empirical analysis. This article consists of five parts including short Introduction and Conclusion. Part two will display historical backgrounds that lead to the composition of the Rusk Letter. This part will particularly show how the Allied Powers acquired the ownership over Dokdo from the Cairo Declaration to the adoption of the San Francisco Peace Treaty [hereinafter Peace Treaty]. Part three will trace the drafting and forwarding processes of the Rusk Letter. Finally, Part four will look through the contents of the Rusk Letter closely and examine the admissibility of evidence.

1 Ministry of Foreign Affairs of Japan, Takeshima in the San Francisco Peace Treaty (サンフランシスコ平和条約における 竹島の扱い), available at http://www.mofa.go.jp/mofaj/area/takeshima/g_sfjoyaku.html (last visited on Jan. 1, 2014).

2 Ministry of Foreign Affairs of Japan, 10 Issues of Takeshima, available at http://www.mofa.go.jp/region/asia-paci/ takeshima/pamphlet_e.pdf(last visited on Jan. 7, 2014).

3 Ministry of Foreign Affairs of Japan, Takeshima: What do you know about Takeshima?, available at http://www.mofa. go.jp/mofaj/area/takeshima (last visited on Jan. 1.2014). 


\section{Background}

In November 1943, President Franklin D. Roosevelt (US), Prime Minister Winston Churchill (UK), and President Kai-shek Chiage (ROC) gathered in Cairo, Egypt. At this meeting, they agreed to end the Second World War as soon as possible and to suggest a blueprint of postwar world order at the 'Cairo Declaration'. This declaration clarifies that: "Japan will also be expelled from all other territories which she has taken by violence and greed." It also reads: "The aforesaid three great powers, mindful of the enslavement of the people of Korea, are determined that in due course Korea shall become free and independent." ${ }^{5}$

The Cairo Declaration was merged into the Potsdam Declaration which was issued on July 26, 1945 . $^{6}$ These two declarations became legally effective as Japan proclaimed her unconditional surrender in August 15, 1945 and finally signed the "instrument of surrender" on September 2, 1945 which recognized the adoption of the Potsdam Declaration. ${ }^{7}$ The Potsdam Declaration limited the sovereignty of Japan as follows.

The terms of the Cairo Declaration shall be carried out and Japanese sovereignty shall be limited to the islands of Honshu, Hokkaido, Kyushu, Shikoku and such minor islands as we

4 See Records on the Summits of the Allied Powers including US, UK and USSR: Cairo, Yalta, Potsdam, etc. (第二次世 界大戦中二於ケル米英蘇ソノ他連合国首脳者会談関係一件: カイロ、ヤルタ、ポツダム会談等), Ref.B02033037200, Vol. 1 (A-7-0-381) (Ministry of Foreign Affairs of Japan Diplomatic Archives: JACAR アジア歴史資料センター).

5 Id. It states: "Japan will also be expelled from all other territories which she has taken by violence and greed. The aforesaid three great powers, mindful of the enslavement of the people of Korea, are determined that in due course Korea shallbecome free and independent."

6 Id. It states: "8. The terms of the Cairo Declaration shall be carried out and Japanese sovereignty shall be limited to the islands of Honshu, Hokkaido, Kyushu, Shikoku and such minor islands as we determine."

7 See Instrument of Surrender (Sept. 2, 1945), in Japan's Foreign Relations-Basic Documents vol.1, at 77-79. It states: We, acting by command of and in behalf of the Emperor of Japan, the Japanese Government and the Japanese Imperial General Headquarters, hereby accept the provisions set forth in the declaration issued by the heads of the Governments of the United States, China and Great Britain on 26 July 1945, at Potsdam, and subsequently adhered to by the Union of Soviet Socialist Republics, which four powers are hereafter referred to as the Allied Powers. We hereby proclaim the unconditional surrender to the Allied Powers of the Japanese Imperial General Headquarters and of all Japanese armed forces and all armed forces under Japanese control wherever situated. ........ We hereby undertake for the Emperor, the Japanese Government and their successors to carry out the provisions of the Potsdam Declaration in good faith, and to issue whatever orders and take whatever action may be required by the Supreme Commander for the Allied Powers or by any other designated representative of the Allied Powers for the purpose of giving effect to that Declaration. ......... The authority of the Emperor and the Japanese Government to rule the state shall be subject to the Supreme Commander for the Allied Powers who will take such steps as he deems proper to effectuate these terms of surrender. [Signed at Tokyo Bay, Japan at 0904 on the Second day of September, 1945.] [Emphasis added] 
determine. ${ }^{8}$

However, such a stand of the Allied Powers has altered several times since the first draft of the Peace Treaty. Dokdo was originally ascribed as a part of Korean territory in the five drafts adopted from March 20, 1947 to November 2, 1949. ${ }^{9}$ The content of the draft of November 2, 1949, under Article 6 establishes Dokdo as an island of Korea as follows:

1. Japan hereby renounces in favor of Korea all rights and titles to the Korean mainland territory and all offshore Korean islands, including Quelpart, the Man How group which forms Port Hamilton, Dagelet Islands, Liancourt Rocks (Takeshima), and all other islands and islets... ${ }^{10}$

However, Article 3 of the draft Treaty of Peace with Japan dated December 8, 1949 lists Dokdo as an island of Japan, as follows.

The territory of Japan shall comprise the four principal Japanese islands of Honsyu, Kyusyu, Shikoku and Hokkaido and all adjacent minor islands, including the islanda of the Inland Sea (Seto Naokai); Tsushima, Takeshima (Liancourt Rocks)... ${ }^{11}$

This sudden change was arguably due to the interventions of William J. Sebald, the US Political Adviser for Japan, who was then living in Japan. Sebald wrote a telegram supporting Japan's claim to the US Department of State on November 14 of 1949. ${ }^{12}$ The US Department of State accepted Sebald's opinion and listed Dokdo as an island of Japan in the draft of December 8, 1949. ${ }^{13}$ However, the new draft proposed on December 19, 1949 included Dokdo in territory of Korea, again, as follows.

8 Supra note 4.

9 Yongha Shin, 3 Materials On DoKdo SoverEIGNTy (독도영유권 자료의 탐구) 300-301 (2000).

10 US Department of State, "Treaty of Peace with Japan, Dated on Nov. 2, 1949 [USNARA/Doc. No.: N/A]. [Emphasis added]

11 US Department of State, Office Memorandum from Samuel W. Boggs to Maxwell M. Hamilton and Robert A. Fearey: Draft Treaty of Peace with Japan, Territorial Clauses, Dec.8, 1949 [USNARA/Doc. No. : N/A]. [Emphasis added]

12 See Incoming Telegram by William J. Sebald, US Political Adviser for Japan, to Secretary of State, Nov. 14, 1949 [USNARA/740.0011 PW(PEACE)/11-1949]. It states: “Article 6 : Recommend reconsideration Liancourt Rocks (Takeshima). Japan's claim to these islands is old and appears valid. Security considerations might conceivably envisage weather and radar stations thereon US Department of State."

13 Supra note 11. It states: "The territory of Japan shall comprise the four Japanese islands of Honshu, Kyushu, Shikoku and Hokkaido and all adjacent minor islands, including......Takeshima(Liancourt Rocks).....," 
All Allied and Associated Powers agree that there shall be transferred in full sovereignty to the Republic of Korea all rights and titles to the Korean mainland territory and all offshore Korean islands, including Quelpart (Saishu to), the Man How group (San To, or Komun Do) which forms Port Hamilton (Tonaikai), Dagelet Islands (Utsuryo To, or Matsu Shima), Liancouurt Rocks (Takeshima), and all other islands and islets... ${ }^{14}$

However, the draft dated December 29, 1949, stating Dokdo as 'Takeshima,' reverted it to Japan.

Takeshima (Liancourt Rocks) - The two uninhabited islets of Takeshima, almost equidistant from Japan and Korea in the Japan Sea, were formally claimed by Japan in 1905, apparently without protest by Korea, and placed under the jurisdiction of the Oki Islands Branch Office of Shimane Prefecture... Takeshima has no Korean name and does not appear ever to have been claimed by Korea... ${ }^{15}$

Such alterations may have been caused by divided opinions inside the US Department of State as well as oppositions from other Allies Powers.

Meanwhile, the UK saw the necessity to bring a new draft which can substitute that of the US, thereby autonomously making its own draft of Peace Treaty. ${ }^{16}$ The UK draft clearly recognized Dokdo as a territory of Korea. ${ }^{17}$ In particular, it leaves Dokdo outside of the Japanese territory by displaying alongside it, a besieging line around the mainland of Japan. ${ }^{18}$

14 US Department of State, Agreement respecting the Disposition of Former Japanese Territories, Dec. 19, 1949 [USNARA/Doc. No.: N/A]. [Emphasis added]

15 US Department of State, Draft Treaty of Peace with Japan: Dec. 29, 1949 [USNARA/Doc. No.:N/A].

16 United Kingdom Foreign Office, Provisional Draft of Japanese Peace Treaty (United Kingdom), Apr. 7, 1951 [USNARA/Doc. No.: N/A]

17 Id. It states: "Part I: Territorial Clauses art. 1. Japanese sovereignty shall continue over all the islands and adjacent islets and rocks lying within an area bounded by a line from latitude $30 \mathrm{~N}$ in a north-westerly direction to approximately latitude 33 N. 128 E. then northward between the islands of Quelpart, Fukue-Shima bearing north-easterly between Korea and the islands of Tsushima, continuing in this direction with the islands of Oki-Retto to the south-east and Take Shima to the north-west curving with the coast of Honshu,..."

18 Supra note 15. 
Figure 1: The Territory under Japanese Sovereignty as Defined in Article 1 of the Peace Treaty ${ }^{19}$

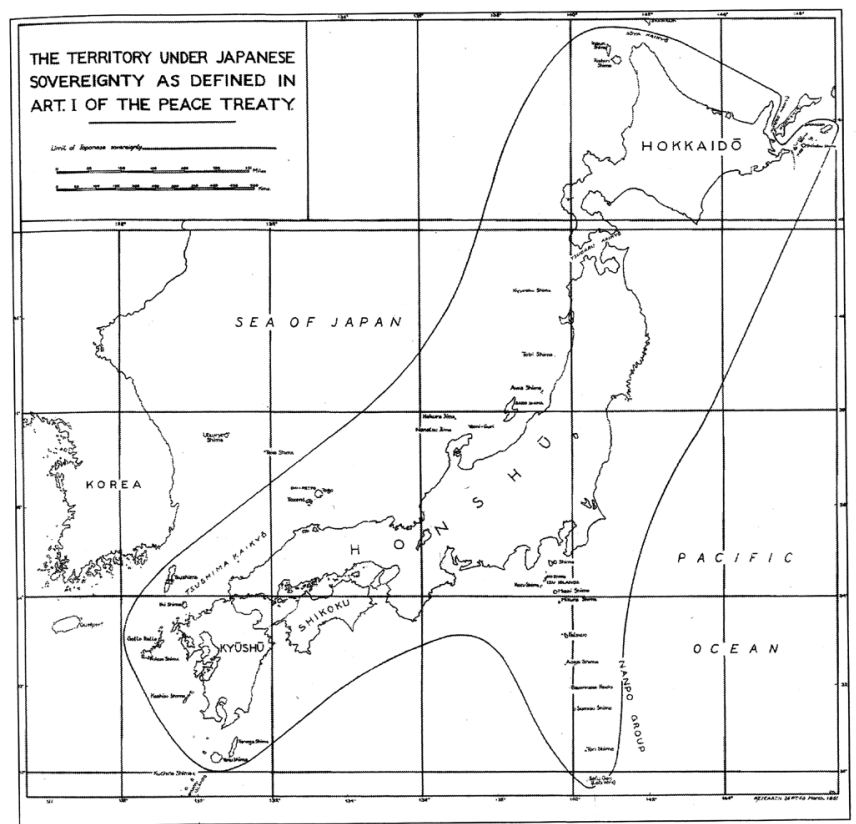

Figure 2: The Maritime Area around Dokdo in the attached Map of the UK $\operatorname{draft}^{20}$

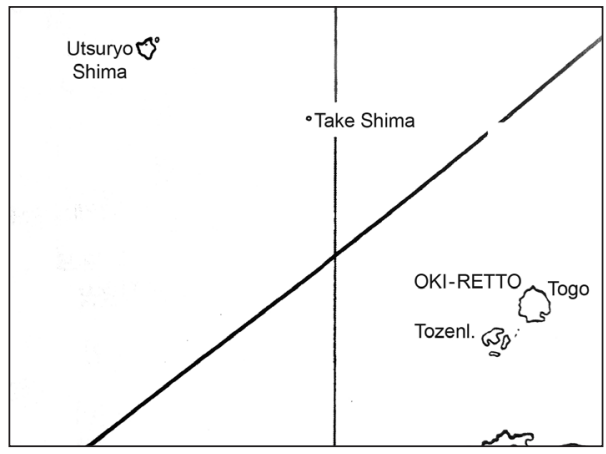

19 The original draft of this map may be found at the US National Archives, recited from BYUNG-Joon JUNG, DoKDO 1947(독도 1947) 577 (2010).

20 Id. This map shows Dokdo is out of Japanese territory. 
The UK draft was almost same with that of US's as on November 2, 1949, which reflects the original agreement of the Allied Powers. After this, both sides held confidential talks seven times, ${ }^{21}$ which finally led to the first US-British draft on May 3, 1951. Article 2 of the US-British draft ambiguously refers to the territory of Korea as follows. [Emphasis added]

(a) Japan, recognizing the independence of Korea, renounces all rights, titles and claims to Korea, including Quelpart, Port Hamilton and Dagelet. ${ }^{22}$

Although there is no mention of Dokdo here, Korea urged to include Dokdo and Parangdo in the Korean territorial clause of the US-British draft. ${ }^{23}$ On June 1, 1951, delegates from eleven member States of the Far Eastern Commission gathered in Washington, D.C. to discuss the US-British Draft. In this conference, a delegate from New Zealand suggested:

In view of the need to ensure that none of the islands near Japan is left in disputed sovereignty, the New Zealand Government favours the precise delimitation by latitude and longitude of the territory to be retained by Japan as suggested in Article 1 of the United Kingdom's draft. ${ }^{24}$

By this proposal (as suggested in Article 1 of the United Kingdom's draft), New Zealand might have the opinion to confirm Dokdo as an island of Korea. The US made the following comment for this proposal.

In the discussions at Washington the British agreed to drop this proposal when the US pointed to the psychological disadvantages of seeming to fence Japan in by a continuous line around Japan. The Japanese had objected to the British proposal when it was discussed with them in Tokyo. US willingness to specify in the treaty that Korean territory included Quelpart, Port Hamilton and Dagelet also helped persuade the British. ${ }^{25}$

It is noteworthy that the US showed the UK draft to the Japanese officers in Tokyo

21 Supra note 9, at 357-358.

22 US Department of State, Draft Japanese Peace Treaty: Reviced on May 3, 1951 [USNARA /694.001/5-351].

23 US Department of State, Office Memorandum to John F. Dulles from John M. Allison: Unresolved Treaty Provisions, May 29, 1951 [USNARA/694.001/5-2951 CS/JEC].

24 US Department of State, Japanese Peace Treaty: Working Draft and Commentary, June 1, 1951. [Emphasis added] 25 Id. 
asking whether or not to accept it. The Japanese objected the British proposal. ${ }^{26}$ It means the UK draft might be very close to the final draft of a Peace Treaty. Moreover, the US did not clarify whether Japan's objection during the Tokyo conference was toward the surrounding line around the Japan mainland, or the insertion of Dokdo into the Korean territory.

To the suggestion by New Zealand, meanwhile, the US emphasized that drawing a visible and exact line surrounding the Japanese mainland might give the psychological pressure to Japanese people; it seem like fencing Japan by drawing a continuous line around its territory. ${ }^{27}$ Yet, the US did not state in public that Dokdo should be included in Japanese territory, neither did the UK admit that Dokdo was a part of Japanese territory under the US-British draft. ${ }^{28}$ Considering all these facts, it is not possible to say that Japan ought to have territorial rights over the islands simply because Dokdo was not directly laid down in the Peace Treaty; listing only three big islets might be a compromise for Japan to accept the treaty.

After the Peace Treaty was adopted on September 8, 1951, the Allied Powers never referred to Dokdo. If Dokdo became a part of Japan under the Peace Treaty, the Allied Powers would have urged Korea to leave the islands. However, neither such official measure made, nor any objection raised towards Korea's effective management of Dokdo as its territory. The Allied Powers acquiesced to the Korean ownership of Dokdo. Although several countries expressed disagreement against South Korean President Syngman Rhee's Declaration of the Peace Line of January 18,1952 , the disaccord was related to fisheries, not the ownership of Dokdo itself. ${ }^{29}$

\section{Writing}

As Korea was not a member of the Peace Treaty, she could not get enough information about the drafting process. When the Korean government recognized that Dokdo was omitted from the final draft of Peace Treaty, it requested the US Department of State to include Dokdo among the islands Japan should renounce.

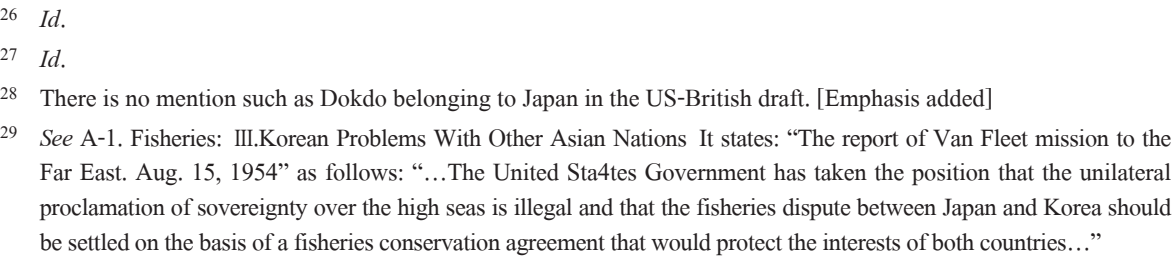
Far East. Aug. 15, 1954" as follows: “...The United Sta4tes Government has taken the position that the unilateral proclamation of sovereignty over the high seas is illegal and that the fisheries dispute between Japan and Korea should be settled on the basis of a fisheries conservation agreement that would protect the interests of both countries..." 
Yu-chan Yang, the Korean Ambassador to the US sent a letter to John F. Dulles, the US delegate to the San Francisco Peace Conference, urging the modification of the Korean territorial clause as follows.

Japan renounced on August 9, 1945, all right, title and claim to Korea and the islands which were part of Korea prior to its annexation by Japan, including the islands Quelpart, Port Hamilton, Dagelet, Dokdo and Parangdo. ${ }^{30}$

On August 10, 1951, the US Department of State dispatched a reply in the name of David Dean Rusk, the Assistant Undersecretary of Cabinet for Far Eastern Affairs. This document, so-called the 'Rusk Letter,' wrote as follows.

\begin{abstract}
...the United States Government does not feel that the Treaty (San Francisco Peace Treaty) should adopt the theory that Japan's acceptance of the Potsdam Declaration on August 9, 1945 constituted a formal or final renunciation of sovereignty by Japan over the areas dealt with in the Declaration. As regards the island of Dokdo, otherwise known as Takeshima or Liancourt Rocks, this normally uninhabited rock formation was according to our information never treated as part of Korea and, since about 1905, has been under the jurisdiction of the Oki Islands Branch Office of Shimane Prefecture of Japan. The island does not appear ever before to have been claimed by Korea. ${ }^{31}$
\end{abstract}

\title{
4. Analysis
}

The Rusk Letter can be summarized as follows: (1) there is no evidence supporting that Dokdo has been a part of Korea before 1905; (2) Korea never claimed sovereignty of Dokdo; and (3) Dokdo has been under jurisdiction of Japan's Oki Islands. Finally, the US Department of State refused the request from the Korean government to specify Dokdo as an island territory for Japan to renounce.

The Rusk Letter's admissibility as evidence should be analyzed from two perspectives. First, it should be clarified on the ground upon which the US State Department referred to the ownership of Dokdo. The Rusk Letter shows it was

30 Supra note 2. See also US Department of State, Memorandum of Conversation: Japanese Peace Treaty, July 19, 1951 [USNARA/694.001/7-1951].

31 Ministry of Foreign Affairs of Japan, Treatment of Takeshima in the San Francisco Peace Treaty, available at http:// www.mofa.go.jp/region/asia-paci/takeshima/treatment.html; http://www.mofa.go.jp/mofaj/area/takeshima/pdfs/g sfjoyaku03.pdf (all last visited on Mar. 22, 2014). 
written on the basis of 'our information. ${ }^{32}$ It is unclear as to what 'our information' in this sentence refers to. In a letter of February 4, 1952 titled "Japanese-Korean Dispute over Liancourt Rocks (Takeshima or Tok-do),” W. G. Jones from the Department of the State explained to the US Ambassador to Japan, Gerald Warner, as to which why Dokdo was part of Japanese, as follows.

In 1947, the Japanese Government published a study Minor Islands Adjacent Japan Proper, Part IV , ... This study states that Japanese had knowledge of the island of Matsushima, presently called Takeshima, from ancient times, and cites a documentary reference in 1667. It asserts that the Koreans have no name of their own for the islets, as they do for Ullung Island a short distance northwest. The island was placed under the Oki Islands Branch Office of Shimane Prefecture on February 22, 1905. The islets have never been settled, except that Oki Island seal hunters who began operations there in 1904 shortly thereafter built temporary summer shelters on the islets, using Ullung Island as their base. The Nihon Hyakka Daijiten(Encyclopedia Japonica), Tokyo Sanseido Press, 1912 VI, p. 880 gives further detail. A Japanese fisherman named Nakai placed a Japanese flag on the islets in $1904 .{ }^{33}$

As discussed above, the US Department of the States' understanding of Dokdo was based mainly on a Japanese encyclopedia. This encyclopedia explains that there was never a Korean title over Dokdo before $1905 .^{34}$ However, this is not true. Until the late nineteenth century, Dokdo had otherwise been called 'Usando. ${ }^{35}$ However, Emperor Kojong of Korea had ordered to remove the name Usando, an old name for Dokdo, since Usando had once been known as Ulleungdo in the early Choson Dynasty, when the exploration of Ulleungdo began. ${ }^{36}$ Japans' official document even acknowledged that Dokdo was once called Dol-sum (literally meaning 'Rocky Island') by those inhabitants who moved to live there and it was later called Dok-sum owning to the dialects of the inhabitants from the Jeolla province, and subsequently the name was changed to Dok-do in $1904 .{ }^{37}$ Therefore, the Japanese

32 The Rusk Letter reads: "this normally uninhabited rock formation was according to our information never treated as part of Korea." [Emphasis added]

33 US Department of State, Office Memorandum: Japanese-Korean Dispute over Liancourt Rocks (Takeshima or Tok-do), Feb. 4, 1952 [USNARA/795.022/2-452, DC/R].

34 Id.

35 See Mangi Yoram(萬機要覧)(1808). It states: "Both Ulleung and Usan are the same territory of Usando. Japanese used to call it Songdo.” (欎陵于山皆于山國地于山則倭所謂松島也)

36 See Kojong Sillok, vol. 19, Article of 1882. 4.7. For the Korean translation of the Kojong Sillok, see The Annals of Joseon Dynasty, available at http://sillok.history.go.kr/viewer/viewtype1.jsp?id=kza_11904007_001\&mTree=0\&inRes ult=0\&indextype $=1$ (last visited on Mar. 23, 2014.)

37 The warship Niidaka recorded in its voyage log on September 25, 1904 that: "Korean people write the name of these islets as Dokdo (独島), and our (Japanese) fishermen call them as Lianco-do, the shortend form of Liancort Rocks, a 
report which claimed that there was no Korean title for Dokdo, is a distortion of its own historical records. Further, this encyclopedia describes that Dokdo was occupied for the first time by Yozaburo Nakai from Japan in 1904 and merged into Oki Islands on February 22, 1905. It shows that the Rusk Letter and Sebald's argument were exclusively based on the Japanese position.

In brief, false information from the Japanese encyclopedia transformed into a request by Sebald to the US Department of State, which finally found way into the Rusk Letter. This, the Japanese encyclopedia further argues: "No information advanced by the ROK in support of these claims is available here," enumerating the Korean newspaper articles of the time. ${ }^{38}$ At the time, the US Department of State had little contact with Korea since she was not a signatory country to the Peace Treaty, while widely accepting Japanese claims through frequent communication. In this unfair and insufficient investigation, the Rusk Letter finally regarded Dokdo as an island of Japan.

Furthermore, the Rusk Letter was not an official diplomatic document with a legal effect. It was proved in a confidential letter dated July 22, 1953 entitled "Possible Methods of Resolving Liancourt Rocks Dispute between Japan and the Republic of Korea." In this letter, L. Burmaster from the department of Northeast Asia in US Department of State wrote to Robert J. G. McClukin the deputy chief of same department that:

\footnotetext{
With regard to the question of who has sovereignty over the Liancourt Rocks(which are also known in Japanese as Takeshima, and in Korean as Dokdo), it may be of interest to recall that the United States position, contained in a note to the Republic of Korea's Ambassador dated August 10, 1951 reads in part ...[mentioned about Rusk Letter]... (This position has never been formally communicated to the Japanese Government but might well come to light were this dispute ever submitted to mediation, conciliation, arbitration or judicial settlement.)... ${ }^{39}$
}

This document clearly indicates that when it was drafted, Japan was not notified of the contents of the Rusk Letter. The Rusk Letter was intended to be a confidential document only to the Korean government. Even the US Embassy in Korea did not know of the existence of the Rusk Letter. When Korea remonstrated with the US for the US-Japan Status of Forces Agreement of 1952 which determined to use Dokdo

French name of these islets.”(韓人之を独島と書し、本邦漁夫等略してリアンコ島と称せり).

38 Supra note 31 .

39 See Possible Methods of Resolving Liancourt Rocks Dispute between Japan and the Republic of Korea (Japan Diet Library Center for Constitutional Sources, LOT Reel 34, 0648-0651.). 
for bombing tests, the US Embassy in Korea released its official statement admitting that Dokdo is a part of Korea as follows.

The Embassy has noted the statement contained in the Ministry's note that 'Dokdo island (Liancourt Rocks) ... is a part of the territory of the Republic of Korea'. The United States Government understands that ownership of this island is in dispute... ${ }^{40}$

Although the US Department of State soon gave instructions to the US Embassy to Korea to modify the statement, the Rusk Letter was obviously unknown even to the core departments of the US government. Another evidence that the Rusk Letter was unfamiliar to the other member States of the Peace Treaty can be found at "The Report of Van Fleet Mission to the Far East." ${ }^{41}$ It was a confidential report made out by James Van Fleet, the US special mission ambassador to the then US President Dwight Eisenhower in August 1954 after a round of visits to Korea, Japan, Taiwan, and the Philippines. In this report, Van Fleet disclosed that:

The Island of Dokto (otherwise called Liancourt and Take Shima) is in the Sea of Japan approximately midway between Korea and Honshu (131.80E, 36.20N). This Island is, in fact, only a group of barren, uninhabited rocks. When the Treaty of Peace with Japan was being drafted, the Republic of Korea asserted its claims to Dokto but the United States concluded that they remained under Japanese sovereignty and the Island was not included among the Islands that Japan released from its ownership under the Peace Treaty. The Republic of Korea has been confidentially informed of the United States position regarding the islands but our position has not been made public. Though the United States considers that the islands are Japanese territory, we have declined to interfere in the dispute. Our position has been that the dispute might properly be referred to the International Court of Justice and this suggestion has been informally conveyed to the Republic of Korea. ${ }^{42}$

As clarified by the above mentioned proof, the Rusk Letter was a confidential correspondence solely made to Korea which was forwarded to neither Japan nor the Allied Powers. Then, only the US considered Dokdo as a part of Japan. As there was no other official discussion on this problem among the Allied Powers, the Rusk Letter cannot be a ground of the Peace Treaty.

\footnotetext{
40 Foreign Service Dispatch, ROK Ministry of Foreign Affairs Note regarding the Bombing of Dokdo Island (Liancourt Rocks), Nov. 19, 1952 [USNARA/694.9513/11-1452].

41 See The report of Van Fleet mission to the Far East. Aug. 15, 1954, A-4 (Ownership of Dokdo Island): III. Korean Problems with Other Asian Nations.

42 Id. [Emphasis added]
} 
In addition, John F. Dulles, the US Ambassador to the Peace Treaty spoke of the Rusk Letter after becoming the Secretary of the Department of State as follows.

However to best our knowledge formal statement US position to ROK in Rusk note August 10, 1951 has not been communicated Japanese. ... US view re Takeshima simply that of one of many signatories to treaty... US should not become involved in territorial dispute arising from Korean claim to Takeshima... ${ }^{43}$

Dulles's statement shows that Japanese sovereignty over Dokdo was but a unilateral stance by the US. It clarifies that the Rusk Letter never influenced the final draft of Peace Treaty.

Moreover, in a document dated October 3, 1952, entitled "Korean on Liancourt Rocks," the US Embassy to Japan explained to the US Department of State and the US Embassy to Korea (then in Pusan) as follows.

\begin{abstract}
...the drafters of the treaty did not include these islands (=Dokdo) within the area to be renounced. Japan has, and with reason, assumed that its sovereignty still extended over these islands. For obvious reasons, the Koreans have disputed this assumption. ${ }^{44}$
\end{abstract}

This document admits that the Japanese territorial claim to Dokdo is an 'assumption.' The US decided not to involve itself in this dispute. The report of the Van Fleet mission to the Far East revealed that it was the sole conclusion of the US that Dokdo was a part of Japanese territory. In other words, it is verified that the interpretation that "Dokdo is Japanese territory" was not concluded by the Allied Powers, yet such an opinion was merely the account of the US.

In the letter to the US Embassy to Japan, Dulles again clarified that it was only the interpretation of the US that Dokdo remained an island of Japan by the Peace Treaty. ${ }^{45}$ L. Burmaster recommended that the US should refuse if Japan asked for the role of mediator as follows.

1. NA/J [Office of Northeast Asian Affairs Japan Devision] recomends that the Department of States take no action at this time in as much as Foreign Minister Okazaki has stated that

43 US Department of State, Outgoing Telegram to AM embassy Tokyo from John F. Dulles. Dec. 8, 1953 [USNARA/694.95B/11-2353]. [Emphasis added]

44 See Korean on Liancourt Rocks, Oct. 3, 1953, Desp. \#659, From AM Embassy Tokyo to AM Embassy Pusan [322-Liancourt Rocks-1952].

45 It states: "Despite US view peace treaty...leaves Takeshima to Japan..., it does not necessarily follow....Japan's international dispute...," See supra note 42. 
the Japanese Government will try to settle the dispute with the ROK Government by direct negotiation.

2. However, if the Japanese Government requests that the United States Government to act a mediator in this dispute, $\mathrm{NA} / \mathrm{J}$ recommends that:

a) the United States should refuse;

b) the United States should suggest that the matter might appropriately be referred to the International Court of Justice. The United States could inform the Japanese Government that this procedure might be preferable to submitting it to the United States for the reasons stated above.

3. If the Japanese Government requests the legal opinion of the United States Government on this question, NA/J recommends that the United States should make available to the Japanese Government the United States position on the Liancourt Rocks as stated in the Rusk note of August 10, 1951. ${ }^{46}$

Dulles's statement was reconfirmed by the document entitled "Conflicting KoreanJapanese Claims to Dokdo Ialand (Otherwise known as Takeshima or Liancourt Rocks)" dated August 26, 1954. ${ }^{47}$ This document raises the question to the probative power of the words, 'our information' as mentioned in the Rusk Letter. ${ }^{48}$ It states:

His [Rusk's] statement left the door open to Korea to show that it has in fact treated Dokdo as a part of Korea prior to 1905, when the Japanese placed Dokdo under the jurisdiction of the Shimane Prefecture of Japan. (Japan established a protectorate over Korea in [1904] and annexed Korea in 1910.) ${ }^{n 99}$ Until 1954, the Korean government officially repeated its position to the sovereignty over Dokdo before $1905{ }^{50}$

"Office of the Assistant legal Advisor for Far Eastern Affairs, Country Files, 1945-1966, Entry 5387, Box 12, 250/63/21/6. "Conflicting Korean-Japanese Claims to Dokdo Island (Otherwise known as Takeshima or Liancourt Rocks), Aug. 26. 1954. [USNARA/Doc. No. RG59]. It reads: "The Department replied referring to the United States view that the treaty of peace "leaves Takeshima to Japan." The Department remarked however that the US view was simply that of one of the several signatories of the Treaty, and that Article 22 of the Peace Treaty (providing for reference to the International Court of Justice) was drafted in order to settle treaty disputes."

48 Id

$49 I d$.

50 E.g., the Korean government proclaimed its legitimacy on the sovereignty of Dokdo on September 9, 1953. See The Korean Government's Refutation of the Japanese Government's Views concerning Dokdo (Takeshima) in Tokyo (July 13, 1953), [USNARA/Doc. No.: N/A]. 


\section{Conclusion}

The so-called Rusk Letter claimed that the Peace Treaty entrusted Dokdo into Japanese administration. Many existing documents have hence proved that the Rusk Letter is but a unilateral stance taken by the US. As a matter of fact, the US would have argued that it was a common understanding between the US and the UK if the UK admitted to Japan's territorial rights over Dokdo in the US-British draft of Peace Treaty. However, the US did not claim such a position. This means that the USBritish draft considered Dokdo as a territory of Korea.

The Rusk Letter was but a confidential document sent only to Korea. The Letter was based on false information. It did not influence the decision of Peace Treaty. Therefore, the Rusk Letter cannot be a critical piece of evidence to Japan's territorial claim over Dokdo. 
